\title{
The work of Daphne Hampson: The God talk of one feminist theologian
}

\author{
Maretha M Jacobs \\ Department of New Testament \\ University of South Africa
}

\begin{abstract}
For almost all of human history both in ancient times and in modern contexts, talk about God has been mainly a male preserve. So closely has male God talk been associated by many with God's own voice, that it is still not commonly realized and acknowledged. With the rise of feminism, especially during recent decades, it has changed. In this article the work of Daphne Hampson, a British feminist theologian, is considered: Her definition and critique of Christianity, her view of the relation between the present and our Christian past, specifically with regard to God talk, her dealing with prominent aspects of the Christian belief system and her emphasis on taking seriously all available knowledge and our contemporary context in doing theology. In line with some current trends in God talk, such as a movement away from anthropomorphism, and in dialogue with Friedrich Schleiermacher, she formulates what she calls a "future theism".
\end{abstract}

\section{INTRODUCTION}

In the column "Kopstukke" in Beeld of 4 February 2006 Willie Burger, professor in Afrikaans literature at the University of Johannesburg, pointed, with reference to Paul Ricoeur, to two kinds of reading of texts: the strategy of "seduction" by a text and that of reading a text "with suspicion". The first kind of reading is about the suspension of disbelief while reading, about enjoying the story and becoming part its world. The second is about reading more carefully, about not suspending disbelief, about the asking of questions to a text, questions such as: How does this text try to influence me? How are the norms and values of a society confirmed by it? Concerned specifically with fictional texts, Burger writes that the strategy of suspicion often destroys the enjoyment of the experience of the "world of the story". Once one has become aware of how certain biases with regard to race, class, gender, religion and economic systems are confirmed by a text, it becomes more difficult to enjoy 


\section{The work of Daphne Hampson}

the enchantment of the "other world". Therefore one should perhaps not blame those who merely read for the joy of it, that is, without taking these matters into account. However, reading "with suspicion" is not without its compensation: it can teach us much about ourselves, our own prejudices and our blind spots.

Although the first kind of reading, a reading of consent, is even in our time still the most common with regard to the reading of biblical texts, as much of biblical scholarship and the mass of popular religious literature make abundantly clear, the latter has for centuries been part of the biblical reading scene. In its subversion of the domestication of biblical texts and prominent figures that they portray historical study of the Bible in its different manifestations can in a sense be regarded as a reading "with suspicion". One only thinks of the clear distinction which is made in Jesus research between the "historical Jesus" (or then "Jesuses") and the dogmatic-popular ones, with the former problematising the latter. Especially during the past few decades more explicit ways of this kind of reading have come to the fore in the form of different kinds of ideological critical readings (Pippin 1997; Fuchs 2004:16). In the case of religious texts and of religion in general this is, of course, complex and contentious. While most readers of biblical writings, like those of fictional texts, would still prefer to read, if not for the joy of it, then for comfort, confirmation and security, aspects of the Christian tradition and its impact, as well as the realities of our own society call in question this kind of reading as the sole one. In the case of the Bible and the Christian tradition a reading "with suspicion" entails looking at familiar writings and matters and at long held views with different eyes and therefore seeing differently, even seeing different things, pointing out origins and biases, asking questions about who wrote and spoke with whom in mind, exposing what is after many centuries of functioning regarded as obviously good as perhaps, even certainly, not so good. In the case of biblical texts a reading with suspicion entails the opposite of a hermeneutics of consent, of the reading of the Bible as religious scripture in which the inerrancy and truth claims of the texts are merely presupposed (Fuchs 2004:6, 7).

\section{FEMINIST/GENDER CRITICISM AS "READING WITH SUSPICION"}

One of the prominent ways of reading "with suspicion" during the past few decades has been reading biblical texts/Christian theology from a feminist/gender perspective, that is, using the analytical tool of gender to investigate the Christian religion, its sources, contexts and practices (Parsons 2002:xiv). Like feminism in general, feminist biblical scholarship and theology 
have during the past few decades become a diverse field in which there have been crucial developments. This is already clear from the use of the plural, of feminisms when referring to this field. An important development within the field, especially in the field of biblical scholarship, which takes seriously the problem of essentialism, has been a move to gender studies (Vorster 2003:69-85). Not only has an immense amount of work been done in this field during the past four decades; a lot of theoretical reflection, including critical self-reflection has taken place, covering matters such as essentialism, discourse theory, the problematisation of "woman" as a universal, detached from matters such as race and class, et cetera (Woodhead 1999; King \& Beattie 2004). Gender-critical thinking in the field of biblical scholarship, theology and religion has indeed become a highly complex and sophisticated matter. Still not "natural" in the current social context, it has, in the words of King (2004:2) to be "intentionally developed through education and involves the radical transformation of consciousness, knowledge, scholarship and social practices". A product of the modern era, and with its roots in the women's movement of the nineteenth century, the way for it has at least partly been paved by critical biblical scholars, liberation theologians, and philosophers of language.

\title{
3. FEMINISM AND CHRISTIANITY
}

One facet of feminist theology, in which this article fits, has been its relation to or encounter with Christianity. In societies where inequality between the sexes is increasingly problematised, the question of feminists' relation to patriarchal religious traditions has in a sense become inevitable. It is therefore understandable that

\begin{abstract}
almost every aspect of the doctrinal, organisational and conceptual identities of Christianity has been subject to some level of feminist enquiry. The nature and depth of this enquiry has often proved to be deeply challenging and sometimes transformative of Christianity. And has resulted in the emergence of what is largely considered to be an identifiable and often radical discourse "feminist theology".
\end{abstract}

(Pears 2004:1)

A crucial question in this debate has been that of the compatibility of Christianity and "feminisms" (Pears 2004:1-3). Most feminist biblical scholars and theologians have remained within the Christian tradition, and thought out new and more liberatory positions within it (Hampson 1998:64), as of course, many liberal male scholars did in the wake of modernity and are in our time 
still doing (cf Berger 1980). This amounts to Christianity becoming, at least for some, an ever broader stream, aspects of which are continually reinterpreted, from which selections are continually made, and to which contemporary values are often first added and then extracted, sometimes consciously but perhaps more often unconsciously. In the field of feminist biblical scholarship/theology a number of options are taken: Scholars opt for strategies such as the radical reinterpretation of the Christian tradition (Carter Heyward), selecting what is regarded as liberatory strands in the tradition (Ruether) or the recovery and reconstruction of (what is regarded as) authentic or original Christianity, where women are thought to have played a more substantial role than has happened in the later stages of Christianity (Schüssler Fiorenza, cf Pears 2004:21ff). Apart from the detection of liberatory impulses within Christianity, reasons given for staying within Christianity, though differently conceived, is usually either that no real alternative is available (King 1999:110), or that no impact for change with regard to the position of women is possible from outside a specific religious tradition (Cady 1999). A few, of whom Mary Daly is perhaps best known, have taken a different route, that of "climbing out" of the tradition and looking at it from a greater distance. It is to one of these scholars, Daphne Hampson, that attention will be paid here. A British systematic theologian, not a biblical scholar, her work can be described as a consistent reading with suspicion of the Christian myth/Christianity and some of its influential interpreters, male scholars as well as feminist ones, though mostly in a nuanced way. If the often quoted statement "Our heritage is our power" with regard to the past and its function in the present is not evident, and may even be untrue with regard to feminist women doing theology, it becomes important to give the word and listen to these women.

\section{THE WORK OF DAPHNE HAMPSON}

\subsection{The scope of her work}

What makes Hampson's work important is that she is in conversation, from a feminist perspective and in a comprehensive and concrete way, with specific aspects of the Christian tradition, to which she poses decisive questions. Significant, too, is that, conversant in mainstream theology, and in conversation with influential male theologians and philosophers, the scope and aim of her work is more comprehensive than feminism(s); her attempt to keep different kinds of insights/interests together; the consistency of her argumentation in an attempt to come up with "a view of her own", specifically with regard to talk on God; her passionate appeal to think in step with 
contemporary insights; the thought - and life - she has brought to her work, which, interrelated as these are in her work, inspire the reader to both thought and life, and the relatedness of her work to some forms of contemporary spirituality.

Reading with suspicion in an academic context is, of course, busying oneself on an intellectual level. This entails the careful definition of one's own position, and the giving of reasons for a view held. This is done extensively by Hampson in her two main books Theology and feminism (1990) and After Christianity (1996, 2002), the book Swallowing a fishbone (1996), of which she is the editor, and a number of articles.

\subsection{Hampson's definition of Christianity and her view of the relation to the past}

How, then does the position from which Hampson questions and argues look like? Her position and views are mainly informed by insights from feminism and those of the Enlightenment, which are, of course, not unrelated (cf Parsons 2002:xiii). Of her book After Christianity she wrote: "The basis of this book is that women (and therefore also men) are in a very different place to where they have been during the long years of Christian history. This cannot but have a profound influence on our religion" (Hampson 2002:xi). The other main aspect of her position is the Enlightenment and insights resulting from it. In fact, along with crucial feminist issues such as the emphasis on equality and justice, and what she calls "a different view of the world", feminism partly has its roots in the fact that women started to think for themselves. It is precisely the insights which followed from the Enlightenment that make what she calls the "particularity" of Christianity problematic: "Thus it is impossible, according to what we now know about the world, that there could have been the 'particularity' which Christianity presupposes and is predicated upon, that is, some kind of 'interruption' in the causal nexus of history and nature" (Hampson 2002:xi, xiv). Not only did the Enlightenment provide us with a different view of the world; it also resulted in a different view of human beings. Part of the post-Enlightenment world, which forms the setting from which the task of theology is undertaken today, at least in the West, is that it is a context in which "humans have come into their own" (Hampson 2002:xi). In her view this calls for a different conceptualisation of God than that of pre-modern, patriarchal times.

Related to feminist and Enlightenment insights is her historical consciousness, which makes her extremely critical of the "ostrich position", that is the kind of Christian theology according to which the past "revelation" can be transposed into our time "like a self- enclosed capsule and which holds 


\section{The work of Daphne Hampson}

theological truth to exist in a sphere of its own, unaffected by scientific discoveries or knowledge we now have which clashes with what is believed to be biblical revelation" (Hampson 1990:14). Her aim is to be a religious person in tune with everything she knows about the world and her feminism, an intention reflected in one of her articles with the title "to be all of a piece, at peace" (Hampson 1992).

Hampson's critique of Christianity closely coheres with her definition of it. For her Christianity refers to the Christian myth, according to which God intervened in history and is uniquely revealed in Jesus of Nazareth. She finds the implication of this, namely that God was in some sense differently related to particular events in a way which does not apply to other events or periods in history unacceptable (Hampson 2002:6). Not only is "an intervention from above" contrary to what we now know of our world; claims to uniqueness, still essential to most of Christianity, has become increasingly problematic within the context of the world religions. She therefore rejects attempts to retain the uniqueness of Christianity: that of Bultmann who moved the (reality of) the resurrection to a different sphere and that of Kierkegaard who regarded Christianity's truth of a different order (kind) than that of other knowledge (Hampson 1990:65; 2002:2). She also rejects a "broader" definition of Christianity, according to which being Christian merely consists in belonging to or living within the Christian tradition (Hampson 2002:63).

What, for Hampson, aggravates the matter, is that Christianity's nature as a "historical religion" implies that the history to which Christians necessarily have to refer, which is in some sense normative for them, is a patriarchal history. What she realises, and concretely spells out, is that ancient patriarchal contexts form part and parcel of what Christians regard as a unique revelation, of its symbol system and of what is still used as sources for answers to present day questions (cf however Hampson and Ruether 1987, Ruether 1990 for a different understanding of what a "historical religion" entails). This causes her to say that not only is Christianity, defined in terms of the Christian myth, not true; in its view on women it is not moral (Hampson 2002:xiii). She is therefore critical of attempts by feminist scholars who, realising the gap between past and present and taking the patriarchal context of biblical texts seriously, try to find a more ethical solution with regard to the relation between past and present than regarding its norms as a blueprint for the present (Hampson 1990:22).

She has been criticised for defining Christianity too narrowly and rigidly, and for the fact that her rejection of it as untrue is based on the view that Christians take aspects of their belief system (myth) such as the virgin birth and the resurrection literally, matters which could also be interpreted 
metaphorically (e g Hampson and Ruether1987:3). And for the role of Enlightenment thought in her work. To define Christianity, as she does, in terms of the uniqueness of Jesus is, according to her, not a conservative position, as some of her critics maintain, but its widest possible definition (Hampson 1994:210; cf Tarnas 1991:113). Even if less rigidly defined, Christianity still necessarily has one foot in the past, making this past in some sense normative for present day people (Hampson 2002:51). This is clear from the fact that Christians usually do not merely decide in the light of present day insights what is ethical in and for their own time; they have to draw on the Bible, on the past for answers to present day questions. With regard to how the Bible is still implemented today, Hampson recalls how in 1978 she was on a committee of the Anglican Church which had to decide whether Phoebe, the co-worker of Paul, was not simply a "deaconess" but a "deacon" in order to admit contemporary women to the office of deacon (Hampson 1990:31). Like many feminist scholars, she is fully aware of reductionist tendencies within Enlightenment thought and of the fact that it often did not favour women (Hampson 2002:6, 7). There is, however, in her view no going back behind these insights. Her position is actually more nuanced than what she sometimes gets credit for. While of the opinion that Christianity as a myth has been the lens that has formed people's understanding of God in the West, she does point out that "some theological statements, by some Christian thinkers, may be profoundly true" (Hampson 1994:214). And, though she wants the myth discarded in our time, she regards it as a past vehicle of something valid, namely human religious experience (1994:214).

If Hampson's work may have, in the eyes of some of her critics, a modernistic slant, it should be remembered that the spirit of our so-called postmodern time does not exclude, but includes "virtually every important element of the Western intellectual past ... forms of the modern sensibility, of the scientific mind, of Romanticism and the Enlightenment ..." (Tarnas 1990: $402,403)$. Postmodernism is no instant way out of the problems posed by modernism. Refraining from beating about the bush, as Hampson does, may be helpful in view of the fundamentalist tendencies which are again in our time becoming characteristic of much of contemporary Christianity.

That Hampson is on the spot with regard to the perceived nature of Christianity and the way the Bible still functions within much of it, is clear from a number of recent events in churches within the South African society. While the Dutch Reformed church recently decided on the bodily resurrection of Jesus, and by implication an "intervention from above", as the linchpin of Christian identity, the Reformed churches are still searching the Scriptures for 
the will of God with regard to the admission of women to the church offices. Not to mention the book and video "Five minutes after death" recently produced by the president of the Apostolic Faith Mission, where Christians who do not conform to orthodox dogmas are unashamedly sent to hell. A possible non-exclusivist, non-fundamentalist and tolerant variety of Christianity seemingly only exists, and is allowed to exist, in academic biblical scholarship and theology unattached to a specific church (cf Tarnas 1991:91119). Hampson's position "After Christianity" is meant in a double sense.

The position that I advocate is clearly after Christianity in that I think the myth of Christianity untenable on both moral and epistemological grounds ... But I am clear that it is in some sense after Christianity (and to some extent after Judaism) that we engage with these issues. Anyone who has had even a glimpse into other cultures ... will recognise the profound difference in thought and presuppositions.

(Hampson 2002:xiii)

She clearly thinks and writes from within the Western tradition, and admittedly does so. This implies that she does not pretend to speak on behalf of all women. It also implies that her position does not entail a total discontinuity with the past. She points out that we are indeed all embedded in religious traditions and cultures by which we have inevitably been influenced (2002:xviii). In her attempt at reconceptualising God she relies especially on the work of the liberal Protestant theologian Friedrich Schleiermacher. There is, according to her, moreover, no reason why we should reject all that has been best about our Christian culture, not least its moral teaching (where that has been good), and its emphasis, for example on the value of persons (2002:xiii). "Human religion should, however, be historical in the sense in which other subjects and endeavours are historical ... we shall have the freedom to draw on the past as we will and to discard what we will" (2002:51). This is a different relation to the past than that brought about by even radical reinterpretation of texts/traditions.

\subsection{Limits on reinterpretation?}

The validity of reinterpretation, a central issue in Hampson's work, though presently crucial for feminist scholars and other forms of liberation theology, is of wider significance for the field of biblical scholarship and theology; it has not disappeared from the scene with the dawn of postmodernism and poststructuralism and the realisation, by philosophers of language, of the instability of language (cf Tarnas 1991:399). A classic statement of this 
problem in a work of fiction is found in the conversation between Alice and Humpty Dumpty in Lewis Carroll's Through the looking-glass, commented upon by William Hamilton in his book The quest for the post-historical Jesus (1993), where the issue of reinterpretation is also at stake. In the conversation between Humpty Dumpty and Alice, Humpty Dumpty is of the opinion that, when he uses a word, it means just what he chooses it to mean. For him the real question is in the end "who is to be master" - that's all. Alice, however, questions "whether you can make words mean so many different things" (Hamilton 1993:10). Commenting on this, Hamilton points out that the issue here is precisely that of the limits that can be imposed on the project of redefinition or reinterpretation. While the theological Humptys feel free in the name of relevance and liberation to reinterpret drastically, the Alices are of the opinion that the past of a word, the ways it has been used, have to be respected. One therefore cannot make a word mean whatever you choose. "If you cannot believe what the word has once meant, you may not make up new meanings for it; you must do without it or invent altogether new words that do not claim to be interpretations of the old" (Hamilton 1993:12). In the case of a two thousand old religious tradition this is, of course, even more complex. With regard to the question of revisioning/reinterpretation Hamilton interestingly refers specifically to feminist theologians, where this is commonly done (cf O'Connor 1995; Pears 2004). It is clear that Hampson's work fits into Alice's view of language, or then the limits she puts on reinterpretation.

"Words must mean something" she wrote in the book Swallowing a fishbone, in which she is in conversation with a number of feminist theologians. "There is no point in understanding by Christianity something it does not and cannot be stretched to mean" (Hampson 1996:3). In this regard she refers to the tendency among women who seek to remain within Christianity to twist Christianity to mean whatever they will. She thinks there is a certain dishonesty in this (Hampson 1996:3). Her kind of reading with suspicion therefore does not have two sides, as in the case of many other feminist theologians. In her case it is about deconstruction, not reconstruction (cf Pippin 1997). This would apply even if admitted that Christianity was initially more diverse and framework-less than it would become especially after the fourth century (Ruether 1991; Soskice 1996).

\subsection{Hampson and Schüssler Fiorenza}

Hampson's view of the relation to the past, as well as what may be called her radical orientation to the present and to the future is put into clear perspective and argued forcefully in her article "On not remembering her" (1998) in which she responds to Schüssler Fiorenza's book In memory of her (1983). The 


\section{The work of Daphne Hampson}

underlying question here is what the past can still do for us, specifically what its possibilities to empower are. The ground-breaking work done by Schüssler Fiorenza on early Christianity, in which she exposes the male biasedness of the Christian writings and points to the more substantial roles women in her view played in the early stages of Christianity, has been immensely influential in the field of feminist biblical scholarship and theology. To do justice to her work it has to be dealt with in a comprehensive and nuanced way, which respects its multi-faceted nature. This has been done in recent Festschrifts (2003, 2004). What is of interest here is that her approach to biblical writings and the Christian past is a both-and-one, that of both deconstruction and reconstruction, and one which is both historically and theologically driven (cf Fuchs 2004). While exposing the androcentric nature of biblical texts, she is of the opinion that the agency of women in the past can be reconstructed "in spite of distortion and loss and silence" (Schaberg 2004:viii). In fact, we need a memory of women who have suffered and resisted patriarchal oppression, but "who have also spoken and acted in the power of the Spirit Sophia" (Fuchs 2004:5). In answer to critics, who understand her view as that of propagating an unbroken lineage between contemporary struggles of feminists and the "discipleship of equals" identified by her in early Christianity, she points to the dialectical nature of this relation in her work (Castelli 2004: 43).

In a sense Hampson and Schüssler Fiorenza's work have different foci. As a systematic theologian Hampson is mainly concerned with what Christianity to a large extent became since the fourth century and, at least officially, remained up to the present. Schüssler Fiorenza focuses on what it, according to her, once was, namely a "discipleship of equals". She associates this ideal with Jesus and the earliest Jesus movement (Pears 2004:116). But even if the more remote (and egalitarian?) past of Christianity would be the focus, Hampson questions its potential for empowering present day women. It is not that she questions the project of writing a different kind of history. "Every age rewrites history, and history affects how we view ourselves" (Hampson 1998:65). While a view of the past from a different angle may have the function of showing us how far male history has been biased, that is, makes us aware of what has mostly been invisible, she questions both Schüssler Fiorenza's portrayal of the early Jesus movement as a "discipleship of equals", and that contemporary women should identify with women in the past for their present empowerment (Hampson 1998:66). For this she regards the gap between present and past too big. "More than in any other similar space of time the world for our generation is new ... Is it not the case that ... we should be making our decisions in relation to the world that is coming, rather 
than in relation to even a recent past?" (Hampson 1998:67). As is the case with individual people, we should understand our past in order not to be governed by it, but to be free for the future (Hampson 1998:68). And: "In our age discontinuity would seem to be stronger than continuity. The future is perhaps imaginatively present to us as it has been to no other generation ... Shall we not live more effectively if psychologically we are free from the past?" (Hampson 1998:68, 69). Quoting Carol Christ, she distinguishes between an intellectual and conceptual debt to Western biblical traditions and loyalty to it (Hampson 1998:4). In her view women "should have more guts than to capitulate to some supposed inevitability of having to reread and reinterpret the biblical tradition" (Hampson 1998:76).

In her reflection on and critique of Schüssler Fiorenza Hampson draws attention to an issue crucial to feminist criticism, also dealt with in depth by the Danish biblical scholar Lone Fatum in a number of articles, namely the attempt by feminist scholars to achieve two different results through the one analytical process of feminist critical exegesis: On the one hand exposing the suppression of women by the biblical material, while, on the other, seeking the affirmation of women by this material (Fatum 1989:61). This procedure is according to Fatum prompted by Christian apologetics, which limits feminist exegesis and makes light of the suppressive evidence in the biblical texts and tradition (Fatum 1989:61). For Fatum (1989:62), the exposure of discrimination and suppression is a feminist theological aim in itself. In line with this she problematises the view "that feminist theological insight and experience of spirituality have to be authorized by Scripture, legitimated if not by canon then at least by a canon within the canon". Significantly she refers to this in a careful argued article on Galatians 3:28, one of the Pauline texts usually embraced by feminist scholars as a result of its supposed egalitarian nature and agenda (Fatum 1989:63; cf also Fatum 1991, 2005).

\section{HAMPSON ON PROMINENT FEATURES OF THE CHRISTIAN BELIEF SYSTEM AND CHRISTIAN THOUGHT}

\subsection{A transcendent monotheism}

In dealing with and problematising aspects of Christian thought Hampson is fully aware of the complexity of the matter, and that care should be taken not to reduce the complexity of material which has developed over two thousand years in widely different cultures. She admits that what she deals with is not necessarily true of all Christian theology in all traditions at all times. However, a number of major still influential, one could even add, indispensable themes can be detected (Hampson 2002:119). 


\section{The work of Daphne Hampson}

The first matter she deals with is transcendent monotheism, regarded by her as the most basic theme to Western religion, central to the Hebrew Scriptures, adopted by Christians and probably still representative of the public perception as to what God is (Hampson 2002:123). Much critical work has already been done on monotheism by both Jewish and Christian scholars. With regard to the absolutist tendency which may be integral to this belief, William Hamilton, for example, wrote: "If I believe in one God, I believe in one truth, and I believe I possess that one truth". And: "To possess God is to possess the most powerful possible instrument of self-approval our times have devised, and the mirror of self-approval turns readily into a sword of judgement" (Hamilton 1993:13, 14). What Hampson finds especially problematic is that this God is placed hierarchically above humankind, as selfsufficient and as having absolute power and knowledge. While God is presented as perfect and powerful, humanity is portrayed as weak and sinful. "The point to note here is that a transcendent monotheism, by its very nature, creates that which is "other" than itself. Monotheism makes for hierarchical structures, in which what is God and what is not God are understood by contrast with what the other is" (Hampson 2002:125). Not only does monotheism, conceived in male imagery, imply opposition between God and human beings; according to her, it also had and has social consequences in that it played a role in keeping male hegemony and hierarchy in place (Hampson 2002:126). Monotheism has been integral to western patriarchal culture (Hampson 2002:128). Scholars do point to a correlation between ancient Israel being monotheistic and the way gender was constructed in that society (Hampson 2002:127). It is indeed striking "that the God of monotheism was designated by names which suggested superior males in that society: King, Lord and Judge" (Hampson 2002:127). This reflects an "extrapolation of the human hierarchy into the realm of the divine" (Hampson 2002:5). Whereas this has in the past been regarded as "how it is and should be", it is nowadays realised to be constructed and problematised. The God of monotheism, who allows no competition, who has the first and the last word, under whose control everything is, does, according to Hampson, not fit feminist ideals/values of relationality, heterogeneity, multiplicity and a lack of control (Hampson 2002:129). According to her the social basis which supports such an understanding of God, that of a hierarchical relation between men and women, is in our time rapidly being overcome (Hampson 2002:249). That God is primarily understood as Father in the New Testament does, according to her, not substantially change the divine/human relationship. Referring to the Lord 's Prayer, and the positive elements it contains, even the nobility it reflects, Hampson points out that the characteristics of monotheism are still in 
tact. God is still envisaged to be "in heaven", "a reality both other than ours and which transcends ours", which reflects a patriarchal and hierarchical order (Hampson 2002:129, 130). She admits that the portrayal in the Scriptures of the monotheistic God as powerful, as One who in some instances overturns the unjust structures of society, and the theology related to this view, such as liberation theology, did result in societal change. It is, however, questionable whether this portrayal of God has the power to generate another paradigm of reality than that of "power over" needed in our time (Hampson:2002:132, 133; 1990a:378). While some biblical writings, such as Isaiah, and some theologians do attribute motherly qualities to the male God, this, in Hampson's $(2002: 180,181)$ view, only leads to an expansion of maleness.

\subsection{Humans as sinful beings}

Everyone growing up in a Christian environment will be aware of the centrality of $\sin$ to Christianity's view of human beings. In fact, $\sin$ is such a crucial piece of the Christian puzzle that the Christian myth would probably crumble without it; there would hardly be need for some of its other components. It is this sinfulness which places human beings in apposition to God. Not only does Hampson (2002:142) question the "Fall" into sin by human beings, usually based on a literal, and Augustinian, reading of Genesis 2, 3, as many biblical scholars nowadays do, and the common portrayal in Christianity of human beings as in apposition to God, which presupposes a hierarchical construction of reality. She also questions the major understanding of $\sin$ in the Western tradition, namely sin as pride, which in her and other feminist scholars' view does not fit the position in which women mostly have been during the past centuries (e. g. Saiving 1979). This questioning applies to the recommended cure for this predicament as well, that of "the crucifixion of the sinful self, the self which is centred in itself" (Hampson 1990:127), the "breaking of an old self and the finding of a new" which has been so influential in popular Christian piety and which she relates specifically to the theology of Martin Luther (Hampson 1988a:240; cf Armstrong 2004:63, 64 for this theme within Roman Catholicism; for a thoughtful response to Hampson and a view more sympathetic to that of Luther see Sponheim 1995). In this regard she asks questions such as: Is a twice-born model really useful? Should women not rather come "to themselves", develop what they already have and are (Hampson 1988a:240, 241)? According to her "the Gospel of powerlessness has been appropriated by those to whom it should never have been directed" (Hampson 1988a:239). Since sin has in Christianity often been understood in individualistic terms, as a disruption in the relation between an individual and God, Christian ethics in her view failed "to provide a theoretical foundation for 


\section{The work of Daphne Hampson}

the establishment of wide-ranging social justice" (Hampson 1990:125).

Further: Would women, whose lives are often lived in different kinds of and more interrelated contexts than men, have identified the same problems as fundamental to the human condition, for example the problem of Angst, which has preoccupied so many male theologians (Hampson 1990:137-140)?

Her own view of human beings and her construal of the "self" is in sharp contrast with this. The "self" is in itself a contested entity and has again become a research topic of its own, something to which attention cannot be paid here, where our interest is in Hampson's view. The view of personhood, or of the "self" which functions in her work, informed as it is by modernity, romanticism and feminist ethics, is an autonomous self, of people coming into their own, "to" themselves. This entails thinking for oneself and the taking of responsibility, but excludes the domination of some by others. This is, according to her, not the Christian view, where a revelation or an institution must take precedence over what one would oneself think. And which still includes domination of some by others (Hampson 1996:3). Her view of the autonomous human being is in the end constitutive of her re-conceptualisation of God, in which not only male God talk becomes problematic, but God talk in terms of parenthood (cf under 6 below). The "self" with which she comes up is, however, not an individualistic, isolated one, but what she calls a "self-inrelation". Her view of human beings is indeed much more optimistic than the traditional Christian one (Hampson 2002:38).

If in the Christian tradition the view of human beings has often been extremely pessimistic, this tradition's view of women can be described as the cherry on the (pessimistic) cake. This was often not spotted or acknowledged by male scholars, since the characterisation of women in the Bible and Christianity and the "place" awarded to them were for most of the Christian era regarded as divinely ordained and therefore "natural". When realised, this was and is often still veiled and "solved" by means of the "sugarising" interpretations which has become so characteristic of Christianity, especially but not only in its popular manifestations. Since women entered academic scholarship this has been more clearly realised and made explicit. Here is not the place to deal in detail with this matter (cf Hampson 2002:169-211). A few remarks are in order.

In the well known words of Simone de Beauvior woman has in Western culture been "defined and differentiated with reference to man and not he in reference to her; she is the incidental, the inessential as opposed to the essential. He is the Subject, he is the Absolute - she is the Other" (in Hampson 2002:169). This is true of the biblical writings and Christianity as well and is related to the one-sex model which functioned in the then world, 
expressed inter alia in the influential characterisation by Aristotle of woman as "not another kind of (equal) human being, but a misbegotten male" (Hampson 2002:8). Not only has man in Christianity given woman a "place" (Hampson 2002:169). The main images of woman in Christianity and Christian history, woman as ideal (mostly mother), as complement to the male and as slut, all fit into the "scheme" devised by men (Hampson 2002:169-211). What is, according to Hampson, lacking in the male construal, also evident in, for example, the portrayal of the virgin Mary, is a sense of woman as an independent agent (Hampson 2002:174).

\subsection{Jesus}

How does her standing outside Christianity affect her view of Jesus, and what is in systematic theology called Christology? Her view of Jesus (and in the end of Christology) should be related to her historical consciousness and her position "after Christianity", from which the need to "twist and save", to keep Christian dogmas about Jesus in tact and to succumb to "the peril of modernising Jesus" (Cadbury 1961) vanishes. The broad contours of her view about him are in line with what most historical Jesus scholars would nowadays acknowledge: That Jesus was someone deeply in tune with (his) God, who lived with trust in (his) God and that he was a teacher and healer. She even thinks that Jesus, as no one else in Western history, was able to actualise God in the world (Hampson 1997:95). And admits that, as a Western person, her understanding of God has at least partly been shaped by Jesus of Nazareth (Hampson 1990:63, 64).

With regard to Jesus and women she, unlike many feminist Christian biblical scholars and theologians as well as male scholars sympathetic to women's cause, resists the temptation of bringing Jesus in line with feminist ideals, rather taking historical insights seriously. For Jesus as "feminist" there is, according to her, "not a shred of evidence". This is not to blame him or to regard him as a misogynist, but to take seriously his society and Jesus as part of it, where not even the minimum definition of feminism, that of equality between men and women, prevailed. In her words: "Indeed, one might well say how could such equality have occurred to Jesus, given the society in which he lived" (Hampson 1990:87). "He was in no ways concerned with those issues which must concern us" (Hampson 1990:90). That Jesus first appeared to women, often regarded as evidence of his revolutionary attitude towards them, should be understood in relation to the long history of women as mourners and attendants to the dead. Hampson quotes with consent the words of Judith Ochshorn, a scholar of near eastern culture: "Jesus was neither a feminist nor a misogynist. His central message simply lay 
elsewhere". This is in line with current historical scholarship on Jesus and women, for example the recent collection of essays by Kathleen Corley (2002). It is, according to Hampson, especially the male symbolism of Christianity, in which Christ as male is seen as representative of (a male) God, which has been harmful to women, privileging males and distorting human relationships (Hampson 1990:75-78). Of this she is extremely critical (Hampson 1990:50-80).

\subsection{The theme of sacrifice}

The theme of sacrifice, central to Judaism and deeply ingrained in the Christian psyche as a means by which the gap between the good God and sinful human beings is bridged, also receives critical attention in Hampson's work. Feminist scholars in general are negatively disposed towards this idea (Brown \& Bohn 1989), which has been closely related to violence (cf Girard 2003). Both the command to Abraham to sacrifice Isaac and Jesus' death interpreted as a sacrifice are problematised by Hampson. In the case of the former she refers to Kierkegaard's Fear and Trembling, where he discusses the Abraham and Isaac episode, and where he calls God's command to Abraham a "teleological" suspension of the ethical. That the ethical relation to others, that is not to kill, can be suspended by a countermand from God, is according to her the consequence of conceiving God as other than creation. Such a demand opens up the possibility that the will of God can contravene what human beings perceive to be right (Hampson 2002:137). While, in dealing with this episode, the emphasis is often on the positive of Abraham's unconditional obedience, with her the emphasis shifts to the question of what kind of God those believed in who transmitted the story of Abraham and Isaac over generations. "How could 'he' play with humans in this manner, to test absolute loyalty to 'him'" (Hampson 2002:142)? She, interestingly, refers to a midrash on this passage written by a feminist scholar, in which inter alia the following words are put into the mouth of Sarah, questioning Abraham's unconditional obedience: "What kind of God would want you to kill your own son to prove how religious you are? ... She's trying to teach you something; that you must challenge even the highest authority on questions of right and wrong. Argue with Her, wrestle with Her! But Sarah's words smacked to Abraham of blasphemy, and he went into the mountains with his Son Isaac" (Hampson 2002:139). Though the "historical Sarah" would hardly have been able to utter these words, a modern one helps us to look at this episode with different eyes.

The theme of sacrifice, specifically the death of Jesus interpreted in this way, present in the Pauline letters and in the letter to the Hebrews, is still 
reiterated endlessly in the Christian churches. It is "the mechanism through which God's wrath is held to be turned into forgiveness" (Hampson 2002: 149). In this regard one thinks of the millions that flocked to Mel Gibson's The passion of the Christ, and the statements one still hears from some pulpits that "God wanted to see blood" or even "that He had to kill Jesus". Why has this theme been so influential, especially in the form of the Anselmian doctrine, where Christ pays a recompense for $\sin$ ? On the theme of sacrifice, and the view of God it presupposes, Hampson quotes the following words of a former Catholic priest, who does not think that this is the message of the Gospel: "At the core of these is a violent God who can never be satisfied with the human project ... The key apparatus and conceptual grip of this God is ritual sacrifice involving an innocent victim, something ... deeply embedded in our thinking". With regard to Jesus' death on the cross he writes: "... one event in Scripture obliterates in significance all other events: the Crucifixion" (2002:151). While not all of Christianity has been like this, many Christians are still of the opinion that this is what Christianity is primarily about.

\subsection{The maleness of the Christian symbol system and its effects}

Though the maleness (and male-constructedness) of the Christian symbol system is already implicit in the above, and should by now be evident, before coming to Hampson's own view it is appropriate to again refer to it in passing. According to John Hick the relativity of religion to human cultures, the fact that the forms of religious belief, experience and practice are culturally conditioned, is today common knowledge - though like many other aspects of modern knowledge it has had to push its way to general consciousness against the weight of pre-modern dogmas. The maleness of God in biblical religions not only reflects but validates the patriarchal human societies whose traditions they are. To affirm a divine reality - which Hick does - is not to claim that that reality is accurately defined by those concepts (Hick 1989:202).

The realisation of the effect of religious symbol systems is not restricted to feminist biblical scholars and theologians. Realising the powerful effect of symbols, the conservative Christian apologist C S Lewis, for example, wrote that a child who had been taught to pray to a Mother in heaven would have a religious life radically different from that of a Christian child. For him, as for most conservatives through the centuries and up to the present, the masculine imagery is given, that is, inspired (Hampson 1990:82). The male constructedness of biblical God talk has been made invisible by the concept of divine revelation and has for many centuries gone unnoticed, since for most of Christian history male insiders were regarded as God's official and legitimate spokespersons. There were therefore only male interpreters of the traditions. 
Not only were women up to the present not involved in conceptualising God; as part of a patriarchal world they did not even understand that there was such a question (Hampson 2002:257). In fact, in most contemporary Christian circles it is still not realised that the biblical images are metaphors for God, not descriptions of "Him".

\section{A DIFFERENT KIND OF GOD TALK}

What if the male metaphors are not given, if they originated in specific social contexts, which they reflect (Hampson 1990:81)? This is clearly the view taken by Hampson as she sets out to come up with a "theism" that will, according to her, be in line with the insights and needs of our time, and will not endorse sexism. In doing this, we shall, according to her, "be doing no more than did others in their time, drawing on the cultural milieu in which they lived" (Hampson 1990:171).

The ideal of religion without dogma, hierarchy and absolutism, and in step with one's own time, as well as the question of one's relation to religious traditions/symbols, crucial to Hampson's work is, of course, not an exclusively feminist one, nor a new one - though from a feminist perspective it acquires a more pointed dimension. Apart from the work of liberal Christian scholars, this is, for example, dealt with in compelling ways in works of literature. In a lecture called "Is nothing sacred?" the Muslim writer Salman Rushdie addressed the question whether the religious mentality can survive outside of religious dogma and hierarchy (Hamilton 1993:2). According to him the great religions are now engaged in the task of keeping us from religion - something in which we should not allow them to succeed. In the interpretation and ordering of religiousness the artist may in Rushdie's view be of help (Hamilton 1993:4). In the Australian novelist Patrick White's Riders in the chariot religious issues are indeed central. All four main characters in the novel lead religious lives, though only two of them are conventionally religious. Even these are not merely confirmers of received tradition, but seekers of the truth and of meaning in dialogue with their religious traditions. In the black American writer Alice Walker's moving The Color Purple, dealt with in some detail by Hampson (1990:162-167), in Theology and feminism, the main character is led by her woman friend to a different view of God after she had suffered immensely from her relationships with her father and husband, which affects her view of God as traditionally conceived and results in questioning "Him". With "man off her eyeball", according to her friend for her a prerequisite for reaching a different view of God, God is, for her, no longer male, no longer conceived anthropomorphically, but part of the one reality of all that is (Hampson 1990:166). 
To return to Hampson's work: In the introductions to both her major books, and by means of occasional brief remarks dispersed through her work, the reader is prepared for her own attempt at God talk which would follow on her discussion and criticism of Christianity. While she is not, as many other feminist theologians, concerned with a reinterpretation/revisioning of Christianity which would meet the needs of feminist women, she does intend to reinterpret what being a religious person might entail (Hampson 1990:1). This is for her even an urgent matter (Hampson 2002:xxii). In addition to crucial aspects of her "outfit" discussed up to now such as her taking seriously of the modern view of the world and of history, and various insights of feminist scholarship, among others the view of the human person as autonomous and related which it espouses, spirituality is in her work never totally out of sight. In fact, characteristic of her work is an attempt to keep it together with other crucial aspects of her work, even at times arguing from it. In contrast to other contemporary theological positions such as non-realism, mainly associated with the work of Don Cupitt in England, continuity with the past lies, for her, not in the retaining of language and symbols regarded to no longer refer to something "outside" themselves, but in a qualified "theism". While many would disagree, and indeed disagree with her view (Ruether 1987; Coakly 1991; Anderson 1993), the amount of thought - and life - which she brings to her God talk, integrated as these are in her work, gives to it an honesty and integrity in a field where the "private" and "public" often still exist, and are allowed to exist, separately. That her work is not merely or only intended for women (Hampson 2002:xx), and has more than feminist interests in view, should be clear from the matters which she addresses; it forms part of a larger endeavour, of what Peter Berger calls "the heretical imperative" in theology which has become necessary in the aftermath of modernity, characterised by pluralisation and the move from fate to choice, with inevitable implications for religion (Berger 1980:11). While in many other cases this entails or has entailed a struggle with the Christian tradition (e g Marcus Borg from the perspective of historical Jesus research and the feminist scholars mentioned above), she has taken a different route, in that she detaches God talk from the Christian belief system. If at this time it has already become clear why she characterises her position as "After Christianity", this is confirmed in her dealing with (the concept of) God and her own reconceptualisation of it. In line with her conviction that conceptualisations of God are related to specific social and cultural contexts, she intends to come up with a notion of God which will be "tenable in this day and age" (Hampson 1990:48), and which will respond to the advance in human knowledge and human ethical standards (Hampson 
1997:98). In her view there is no privileged age, which would require that our understanding has to conform to the understanding of that past age (Hampson 1990:171).

\subsection{In dialogue with Schleiermacher}

Though Hampson's thought is related to the non-anthropomorphic way of speaking about God propounded by, for example, Paul Tillich and John Robinson, and to what is nowadays named panentheism (cf Borg 1997), she does not really enter into dialogue with the proponents of these views, or use their terminology. It is to Friedrich Schleiermacher that she turns in her attempt at reconceptualising God, or then expressing what she means by "God". As others in our time do when the issue of religious experience is at stake or in an attempt to think and speak again in and for our time (Burhenn 1995; Geldhof 2004; Berger 1980:125-156). In his On religion: Speeches to its cultured despisers and his later work The Christian faith Schleiermacher made clear his discontentment with orthodox confessional theology and contended with, or then chose to take seriously Enlightenment thought. In his work, as in that of Hampson, the insights of Immanuel Kant play an important role. It is precisely Schleiermacher's response to Kant which Hampson finds crucial and of which she makes use in her work. Schleiermacher, namely, distinguished religion from both knowledge (or science) and morality, thereby coming up with a structured way of thinking about the nature of religious consciousness (Hampson 1999:30) It was the heritage and continuous impact of Kant's epistemology which prevented Schleiermacher from falling back into traditional theistic thinking, though he did remain Christian (Geldhof 2004:90). Apart from Enlightenment thought he was also deeply influenced by Romanticism with its emphasis on "mind-and-heart" (Barzun 2001:465-470) and therefore on the connectedness of things. It is this double heritage which resonates with Hampson, with her emphasis on the intellectual and human autonomy, and on relatedness, epitomised in the feminist view of the "self" as a self-in-relation. Apart from the fact that he distinguished religion from knowledge and morality, she mentions and finds helpful other aspects of his work: that he founded theology in human awareness or experience and not in revelation (cf also Berger 1980:127-156); that for him religion did not essentially consist in propositions; that before dealing, in his speeches, with Christianity he was concerned with religion in general, irrespective of any form it might take, and especially his conceptualising of the "self" as immediately connected to that which is more than the self, which he variously named the universe, the divine and God (Hampson 2002:213). To this can be added his optimistic view of human beings and his view that when religion is alien to 
people's lives it loses its relevance and meaning (Geldhof 2002:99, 108, 109). In Hampson's interpretation of his work, the view of the self as immediately connected to that which is more than the self precludes a heteronomous relation to God, something which her view of human beings as autonomous persons requires: "What I wish to bring to the fore - and what attracts me to Schleiermacher's conceptualisation - is the lack of the possibility of any heteronomy in the human relation to God", a matter on which Schleiermacher has according to her often been misunderstood (Hampson 2002:213, 218; 1996). In his thought human self-consciousness and God-consciousness were indeed closely intertwined (Burhenn 995:147; cf also Hampson 1990a:172; 1990b:374). For him the underlying experience of religion, its essence, was the encountering of the infinite (that is, God) in the finite phenomena of life (Schleiermacher 1958:31). According to Hampson Schleiermacher's founding of theology in human awareness "could not have occurred other than against the background of the Romantic interest in the subjectivity of the human person and belief in the relatedness of the individual to the whole" (Hampson 2002:215).

Schleiermacher's thought and the criticism of it are complex matters which cannot be dealt with here in detail (Hampson 2002:212-223, Geldhof 2004). He has been accused of proposing the existence of a universal religious experience which he regarded as a stable basis on which a tradition rests (cf Geldhof 2004:90 for theologians who have this view). And that he treated religious experience as an immediate consciousness that is not shaped by concepts and beliefs (Proudfoot, in Burhenn 1995:155). It has, however, been argued that Schleiermacher fully realised the embeddedness of experience in historical determinate contexts (Geldhof 2004:101). Hampson is of the opinion that Schleiermacher's thought would even be able to withstand the criticism of those according to whom there cannot be religious experience unpolluted by concepts and beliefs (Hampson 2002:220-223).

\subsection{Hampson on "that reality called God"}

Hampson's own attempt to say something about "that reality which is God" (2002:viii) is less a philosophical justification of faith than an attempt to give expression to what is, for her, clearly a reality, not merely a construct in language (Hampson 1990:169). Her own God talk is based on what she considers to be the "evidence" for a spiritual dimension of reality which she calls God (Hampson 2002:214, 222). What counts for her as "evidence" do not presuppose interventions, a "God of the gaps", which would be incompatible with her view of the world as scientific and interconnected. These entail things that would always and everywhere be potentially possible 


\section{The work of Daphne Hampson}

and are related to a more extensive view of reality than what is commonly acknowledged in a post-Enlightenment age. Examples are given from her own life and from reports sent to the Oxford Religious Experience Research Unit, in which case no move is made from the described phenomena to what they may imply: the efficacy of prayer, healing (mental and physical), intuition or extra-sensory experience and the conviction that "if people go forward in trust (or faith) unexpected coincidences occur. Needs will be provided for or a way forward will open up" (Hampson 2002:227). This leads her to say that "there is more to reality than meets the eye", a spiritual reality which gives rise to what can not always be explained. She admits that the theological move from the "evidence" to what it may be thought to imply will involve a leap (Hampson 2002:230). What she has in mind is clearly something different from a flight into mystery to defend the literalness and uniqueness of one's own belief system.

Religious experience has in our time again become an important topic in talk about God, religion and religious traditions. There is again, from a number of perspectives, a lot of academic reflection on it (Hood 1995). This is true for some of the same reasons as in Schleiermacher's time. The development of historical criticism and currently social scientific study displayed the Christian past as "all too human", while the reality and appreciation, at least by some, of religious diversity makes a special revelation increasingly problematic (Burhenn 1995:146). The obvious place to start is then with human beings and their experiences. With reference to Vergote, Geldhof points out that the term "religious experience" is a fairly recent concept, an inheritance from theories which at the beginning of the twentieth century "sought to explain the origins of religion and to justify their truth and value as founded in an original and emotional form of knowledge" (Geldhof 2004:95). This does not exclude that that to which this term refers could have existed earlier (Geldhof 2004:95). The matter of religious experience is a complex one, beset by various questions which cannot be dealt with here in full. What is the evidential value of what is called religious experience? What complicates possible inferences from it? Two matters pointed out by Burhenn should be noted in passing. On the one hand the discrediting of empiricism as a theory of knowledge resulted in some philosophers arguing for a more positive evaluation of the epistemological value of religious experience (Burhenn 1995:150). On the other hand there is the realisation, in twentieth century philosophy, of the complex relation between language and "reality", and of the role of concepts in shaping religious experience, that is, that religious experience arises through a complex interplay with concepts and beliefs (Burhenn 1995:156, 156; 
Davaney 1987). Hampson is fully aware of these problems. Admitting to the complex relation between language and reality in the wake of deconstruction, even quoting Derrida, she questions the view that "all there is ... is language" (Hampson 1997:96).

One of the reviewers of her books remarks how difficult it is to create a space for God talk and spirituality after Christianity's ethos has dominated for so long (Isherwood 1998). This can be related to Christianity being commonly equated to holding a certain set of beliefs, and the view that without the affirmation these beliefs no religion, and indeed no salvation is possible (Hampson 2002:257). Hampson realises the difficulty of the endeavour. She admits of having a "skinny God", something of which Schleiermacher was also accused (Hampson 2002:253). In her view feminist thought, with its emphasis on relatedness, may provide a context in which a rethinking of the notion of God may be undertaken (Hampson 1990:149). She thinks of God as "a dimension of the totality that is", as "connected to all that is", something greater than ourselves with which we can be "in tune", to which human beings can be open, with which they are interrelated and on which they can draw (Hampson 1998a:247-249; 2002:231, 236). This would be in line with the emphasis on interconnectedness in the current world view (cf Hampson 1988b:341). In the context of this thought something like prayer, and its effect, traditionally associated with a personal God and with some kind of "intervention" can, according to her, still be meaningful, although as yet we have little understanding of its "workings" (Hampson 2002:244). She conceptualises God in a non-hierarchical way, not over against human beings, in opposition to them. God is, moreover, portrayed in non-anthropomorphic terms: not by means of traditional male metaphors, not at all in terms of parenthood, not even, as by some other feminist theologians, by means of "new" life-enhancing personal metaphors such as "lover" and "friend" (Mc Fague 1987). What is, according to her, needed, is a more dynamic view of God, for which she uses terms such as energy, light, love, power and healing (Hampson 2002:251). In discussing prayer, where an "I - Thou" relation, and therefore personal categories, usually functions, she admits that personal categories for God would perhaps at times be inescapable. This has to do with human beings, their needs and their potential for conceptualising and should not be carried over into an attempt to conceptualise God (Hampson 2002:242, 243). That she herself does not completely escape from personal categories, is clear from the use of expressions such as "love of God" and "the relationship between God and the self", usually associated with God conceptualised as a person (Hampson and Ruether 1987:8; Hampson 2002:xiii). 
That her vision is in the end a hopeful one, is clear from the fact that the idea of God has, for her, a transcendental function. This, she again admits, involves a leap of faith, not of the kind that Kierkegaard proposed, but a faith "that the whole is in some way good or makes sense" (Hampson 2002:245). With God no longer regarded as an anthropomorphic agent who can intervene at will, there is in her view a greater emphasis on human responsibility, with (what she regards as) God involved in the process of people coming to themselves (Hampson 2002:238). According to her this view of God also solves the theodicy question (Hampson 2002:234ff).

The way she thinks about religion and the place of human beings becomes clear in her discussion of spirituality and praxis. If religion is no longer tied to a set of beliefs regarded to be objectively true, but about being a certain kind of person, and with human beings awarded a more positive and crucial place in the "scheme of things", the religious scenery changes substantially. Instead of asking how God wants human beings to live, she changes the direction of this question by asking: "Are there certain ways of being in the world which would seem to be prerequisite to gaining awareness of that dimension of reality which I have called God?" (Hampson 2002:258). In this regard she selects a number of refreshingly down to earth "virtues", some of which are emphasised by women philosophers such as Iris Murdoch and Martha Nussbaum: honesty and integrity, attention and the ordering of one's life (cf Hampson 2002:260ff for a detailed discussion). From her discussion it is clear that the kind of spirituality she proposes is neither otherworldly nor of an instant and opportunistic kind. For Iris Murdoch "attention ... allows a process of deepening and complicating". And according to Martha Nussbaum "Our highest and hardest task is to make ourselves people "on whom nothing is lost"'. Indeed virtues to live by.

\section{CONCLUSION}

Although an attempt has been made to give a fair and representative view of Daphne Hampson's work, it has not been possible to do full justice to the comprehensive nature of her work in an article like this. With the focus on God talk, little attention has, for example, been paid to her view of Christology. It has, moreover, not been possible to do justice to the vibrancy of parts of her writing, and its nearness to life, which contributes to it having a lasting impression at least on this reader. A few concluding remarks are made here, recapitulating some of her crucial insights.

What we have in Hampson's work, as has become clear from the previous pages, is a view at Christianity from the outside by a former insider to Christianity, though never an uncritical one, and one thoroughly versed in the 
tradition she fundamentally critiques. With the observation post changed, and the revelation-tinted glasses removed from the eye of the beholder, one cannot but clearly see the embeddedness of the biblical writings and the Christian symbolism in past patriarchal cultures, the male-constructedness of biblical and Christian God talk, and therefore their bias against women. Since Hampson's position is informed by both feminism and a qualified modernism, some aspects of her critique of Christianity resemble that of contemporary critical male theologians, while the feminist side of her position and critique provides it with an additional, even different dimension. In the case of transcendent monotheism, for example, it is not only the view of a personal God "outside" of our world which she finds problematic, but a male God hierarchically and ethically positioned over against human beings.

With the nature of the Christian past exposed, with it no longer being regarded as the locus of revealed truth and as obvious source for answers to present day questions, the relation between past and present is redefined in a way which differs substantially from that of traditional Christian theology and even some feminist theology. The locus of gravity moves from the past to the present, to contemporary human beings, their contexts and insights. This coheres with Hampson's view of human beings as autonomous and responsible for their lives. Though she does not propose a complete discontinuity with the past, according to her we should in the sphere of religion, as in the case of all human knowledge and ideas, draw on the past when we consider it as true, valid or good, while past insights and values may be jettisoned with the rise of new knowledge or the coming to new moral insights (Hampson 2002:xiii). In a sense this is already happening in some some quarters. One, for example, thinks of the French scholar of religion Hervieu-Léger's reference to the historic religious traditions as "tool-boxes" from which human beings can freely draw in order to make sense of the world and of their own lives, not as pre-packaged answers to their quests (Cox 1995:304, 305).

Significantly, Hampson's rigorous intellectual inquiry and critical scrutiny of Christianity do not result in the eclipse of the spiritual, as often happens. In her God talk the de-compartmentalising tendency in her work is evident: according to her a different view of human beings and of the world inevitably leads to a different view of (what she still calls) "God". Striking is her effort to go about in an argued way and in conversation with someone (Schleiermacher) who partly shares her frame of reference, thus attempting to create a context in which God talk may make sense in changed contexts. Some feminist insights, especially the emphasis on relatedness, are also brought to her attempt at a new kind of God talk. 
By characterising Hampson's work as that of "one feminist theologian" and by referring to a few others, it has from the start been acknowledged that her view is not representative of feminist theologians' view of and relation to Christianity, although there will be some similarities (cf Sawyer 1999). One of the main points of criticism against her work is the definition of Christianity in terms of the Christian myth and of Christians' claim to uniqueness for Jesus as the Christ. This is regarded by her critics as a too restricted definition of Christianity, something to which Hampson (2002:xiv-xv) responded in the introduction to the second edition of After Christianity. Her definition of Christianity as a historical religion in the sense of a unique revelation in the past has been problematised by pointing out that Christianity is a developing and therefore still changing tradition, and that the Scriptures and the Christian tradition contain trends, also with respect to language for God, which counter patriarchal patterns (Ruether 1990). It is pointed out that the God she proposes is not unknown in the Christian tradition (Coakly 1991). Hampson is not unaware of strands in the tradition which correspond to what she wishes to say. This is, however, not the way God has been primarily conceived in Christianity (Hampson 1988a:247). Although more liberatory varieties of Christianity probably did exist through the centuries, and may nowadays function among those with a Christian background who no longer find themselves in the churches, in fairness to Hampson it has to be admitted that a "different" and more "open" kind of Christianity was and is still a rarity and is more or less non-existent in the official manifestations of Christianity. The question how far Christianity, including its major conception of God, can be stretched without losing its identity is a valid one. Even when more idealistic positions are pointed to or thought out within Christianity, it has to be admitted that much of what Hampson says rings true to how it still mostly functions. She indeed raises concerns in a radically pointed way and asks all important questions (Sponheim 1998; Isherwood 1998). While forcefully reminding us of the cultural contructedness of all talk on God, her work also poses the question of spirituality without adherence to a specific religious tradition. While she forces us to think again, and provides us with informed, extensive and fascinating material to think with, her own views may be helpful and open up new possibilities at a time at which many people are, in the sphere of religion, in search of something which makes sense in contemporary contexts and are often thrown on their own resources to explore such possibilities. 


\section{Works consulted}

Anderson, P 1993. "After theology: End or transformation?" Literature \& Theology 7 , 78-86.

Anderson, $\mathrm{P}$ 2002. Feminist theology as philosophy of religion, in The Cambridge Companion to Feminist Theology, 40-59. Cambridge: Cambridge University Press.

Armstrong, K 2004. The spiral staircase. London: HarperCollins.

Barth, K 1972 (1959). Protestant theology in the nineteenth century. London: SCM.

Berger, P 1980. The heretical imperative: Contemporary possibilities of religious affirmation. London: Collins.

Boeve, L \& Hemming, L P (eds) 2004. Divinising experience: Essays in the history of religious experience from Origen to Ricoeur. Leuven: Peeters.

Borg, M J 1997. The God we never knew. New York: HarperSanFrancisco.

Borresen, K E (ed) 1991. Image of God and gender models. Oslo: Solum Forlag.

Brown, J C \& Bohn, C R 1989. Christianity, patriarchy and abuse: A feminist critique. New York: Pilgrim.

Burger, W 2006. Lekker lees of agterdogtig lees? Beeld (Plus), 4 Februarie, p 2.

Burhenn, H 1995. Philosophy and religious experience, in Hood, R W (ed), Handbook of religious experience, 144-160.

Cadbury, H J 1961. The peril of modernizing Jesus. London: SPCK.

Cady, L E 1987. Relational love: A feminist Christian vision, in Cooey et al 1987:135149.

Castelli, E 2004. The Ekklesia of women and/as utopian space: Locating the work of Elizabeth Schüssler Fiorenza in feminist utopian thought, in Schaberg et al (eds), On the cutting edge, 36-52.

Coakley, S 1991. Theology and feminism by Daphne Hampson. Review article. Theology 64, 132-133.

Cooey, P M, Farmer, S A \& Ross, M E 1987. Embodied love: Sensuality and relationship as feminist values. San Francisco, CA: Harper \& Row.

Corley, K E 2002. Women and the historical Jesus: Myths of Christian origins. Santa Rosa, CA: Polebridge.

Cox, H 1995. Fire from heaven. Reading: Addison-Wesley.

Crowder, C 1997. God and reality: Essays on Christian non-realism. London: Mowbray Harrisburg.

Davaney, S G 1987. Problems with feminist theory: Historicity and the search for sure foundations, in Cooey, et al (eds), Embodied love: Sensuality and relationship as feminist values, 79-95. San Francisco, CA: Harper \& Row.

Fatum, L 1989. Women, symbolic universe and structures of silence: Challenges and possibilities in andocentric texts. ST 43, 61-80.

Fatum, L 1991. Image of God and glory of man: Women in the Pauline congregations, in Borresen 1991:56-137. 
Fatum, L 2005. Christ domesticated: The household theology of the Pastorals as political strategy, in Frey, J (ed), The formation of the early church, 175-207. Tübingen: Mohr Siebeck.

Fuchs, E 2004. Points of resonance, in Schaberg, et al (eds), On the cutting edge, 120.

Geldhof, J 2004. On the relative unimportance of religious experience in the early Schleiermacher, in Boeve, \& Hemming 2004:89-112.

Girard, R 2003. From violence and the sacred, in Olson, C (ed), Theory and method in the study of religion: A selection of critical readings, 409-418. Belmont: Wadsworth.

Hamilton, W 1993. A quest for the post-historical Jesus. London: SCM.

Hampson, D \& Ruether, R R 1987. Is there a place for feminists in a Christian Church? New Blackfriars 68, 7-24.

Hampson, D 1988a. On power and gender. Modern Theology 4, 234-249.

Hampson, D 1988b. Luther on the self: A feminist critique. Word and World 8, 334342.

Hampson, D 1990. Theology and feminism. Oxford: Basil Blackwell.

Hampson, D 1992. On being all of a piece/at peace, in Elwes, T (ed), Women's voices: Essays in contemporary feminist theology. London: Marshall Pickering.

Hampson, D 1994. After Christianity: The transformation of theology! Literature \& Theology 8, 209-217.

Hampson, D (ed) 1996. Swallowing a fishbone? London: SPCK.

Hampson, D 1997. On being a non-Christian "realist", in Crowder, C (ed), God and reality: Essays on Christian non-realism, 85-99.

Hampson, D 1998. On not remembering her. Feminist Theology 19, 63-98.

Hampson, D 1999. Re-Review: Friedrich Schleiermacher on religion: Speeches to the cultured among its despisers, 1799. Modern Believing 40, 30-38.

Hampson, M D 2002. After Christianity. $2^{\mathrm{e}}$ ed. London: SCM.

Hick, J 1989. An interpretation of religion: Human responses to the transcendent. New York: Palgrave Macmillan.

Hood, R W (ed) 1995. Handbook of religious experience. Birmingham: Religious Education.

Hyman, G (ed) 2004. New directions in philosophical theology. Aldershot: Ashgate.

Isherwood, L 1998. Hampson, Daphne: After Christianity. Feminist Theology 17, 124125.

King, U (ed) 1995. Religion and gender. Cambridge: Blackwell.

King, U 1999. Feminist theologies in contemporary contexts: A provisional assessment, in Sawyer, D F and Collier, D M (eds), Is there a future for feminist theology?, 100-114.

King, U \& Beattie, T (eds) 2004. Gender, religion and diversity. New York: Continuum. 
Mc Fague, S 1987. Models of God: Theology for an ecological age. Philadelphia, PA: Fortress.

O'Connor, J 1995. Epistemological significance of feminist research in religion, in King, U (ed), Religion and gender, 45-64.

Pears, A 2004. Feminist Christian encounters: The methods and strategies of feminist informed Christian theologies. Aldershot: Ashgate.

Parsons, S F (ed) 2002. The Cambridge Companion to Feminist Theology. Cambridge: Cambridge University Press.

Parsons, S F 2002. Redeeming ethics, in Parsons 2002:206-223.

Pippin, T 1997. Ideological criticisms, liberation criticisms, and womanist and feminist criticisms, in Porter, S (ed), Handbook to the exegesis of the New Testament. Leiden: Brill.

Porter, S E (ed) 1997. Handbook to the exegesis of the New Testament. Leiden: Brill.

Ruether, R R 1990. Is feminism the end of Christianity? A critique of Daphne Hampson's Theology and feminism. Scottish Journal of Theology 43, 390400.

Ruether, R R 1991. Imago Dei, Christian tradition and feminist hermeneutics, in Borresen 1991:258-181.

Saiving, V 1979. The human situation: A feminine view, in Christ, C P and Plaskow, J (eds), Womanspirit rising, 25-42. San Francisco, CA: Harper \& Row.

Sawyer, D F \& Collier, D M (eds) 1999. Is there a future for feminist theology? Sheffield: Sheffield Academic Press.

Schaberg, J, Bach, A \& Fuchs, E 2004. On the cutting edge: The study of women in biblical worlds: Essays in honour of Elizabeth Schüssler Fiorenza. New York: Continuum.

Schleiermacher, F 1958. On religion: Speeches to its cultured despisers, tr by John Oman. New York: Harper \& Row.

Segovia, F F (ed) 2003. Toward a new heaven and a new earth: Essays in honour of Elizabeth Schüssler Fiorenza. Maryknoll: Orbis Books.

Soskice, J M 1996. Turning the symbols, in Hampson, Daphne (ed) 1996. Swallowing a fishbone? 17-32.

Sponheim, P R 1995. On being and becoming before God: A response to Daphne Hampson. Word \& World 15, 332-341.

Tarnas, R 1991. The passion of the Western mind: Understanding the ideas that have shaped our worldview. London: Pimlico.

Tatman, L 2001. Knowledge that matters: A feminist theological paradigm and epistemology. Cleveland: The Pilgrim Press.

Vorster, J N 2003. Engendered strategies of reading, in Bible and gender, SCR309E, 50-131. Pretoria: Unisa.

Woodhead, L 1999. Feminist theology - out of the ghetto?, in Sawyer \& Collier 1999:198-206.

Woodhead, L 2004. Theology: The trouble it's in, in Hyman 2004:173-186. 